\begin{tabular}{l|l}
\hline Potaice & e-ISSN: 2655-9404 p-ISSN: 2721-8376 \\
Vol. 3 No. 1, Februari 2020 & DOI: 10.20473/ntr.v3i1.19024 \\
\hline
\end{tabular}

Article history: Submitted 6 January 2020 ; Accepted 15 January 2020; Available online 1 February 2020.

\title{
Keabsahan Bukti Lama Berupa Letter C Desa Dalam Kepemilikan Hak Atas Tanah
}

\author{
Irsyadilla Hafizh Heru Sadjarwo \\ irsyadilla.hafizh@yahoo.com \\ Universitas Airlangga
}

\begin{abstract}
Land is a primary need in today's life for both residential, business and investment needs. Indonesia had Agrarian Law in 1960. Many parties still held the old evidence on ownership of land rights that had been obtained before the UUPA. One of them analyzed in this study, namely Letter C Desa. In assessing the validity of this evidence it needs to be based on the legal requirements for a decision, which is the appropriate authority, procedure, and object, and needs to be based on the UUPA, Government Regulation on Land Registration, and other relevant laws and regulations. What is the position of old evidence in the form of Letter C Desa in ownership of land rights? What is legal protection for holders of old evidence in the form of Letter C Desa in ownership of land rights? The results of this research show that the Letter C Desa is old proof of ownership of land rights that can be used in land registration activities and legal protection for the holder of the old evidence can be done by negotiation for consensus by the Chairman of the Adjudication Committee in systematic land registration activities and by the Head of the Land Office in sporadic land registration activities. If there are parties who still object, they can file a lawsuit with the District Court for the old evidence.
\end{abstract}

Keywords: Land Law; Land Rights; Old evidence on ownership of land rights; Letter C Desa.

\begin{abstract}
Abstrak
Pertanahan merupakan kebutuhan primer dalam kehidupan saat ini baik untuk keperluan tempat tinggal, usaha, dan investasi. Indonesia baru mempunyai Undang-Undang Pokok Agraria sendiri pada tahun 1960. Banyak pihak yang masih memegang bukti-bukti lama kepemilikan hak atas tanah yang telah diperoleh sebelum adanya UUPA salah satunya yang dianalisis dalam penelitian ini yaitu Letter C Desa. Dalam menilai kebsahan dari Letter C Desa ini perlu didasarkan pada syarat sahnya suatu keputusan yaitu wewenang, prosedur, dan objek yang sesuai serta perlu menberdasarkan UUPA, Peraturan Pemerintah tentang Pendaftaran Tanah, dan peraturan perundang-undangan lain yang berkaitan. Apakah kedudukan bukti lama berupa Letter C Desa dalam kepemilikan hak atas tanah? Apa perlindungan hukum bagi pemegang bukti lama berupa Letter C Desa dalam kepemilikan hak atas tanah?. Hasil dari peneilitan ini menunjukan bahwa Letter C Desa merupakan bukti lama dalam kepemilikan hak atas tanah yang dapat digunakan dalam kegiatan pendaftaran tanah dan perlindungan hukum bagi pemegang bukti lama dapat dilakukan musyawarah mufakat oleh Ketua Panitia Ajudikasi dalam kegiatan pendaftaran tanah secara sistematis dan oleh Kepala Kantor Pertanahan dalam kegiatan pendaftaran tanah secara sporadik. Apabila ada pihak yang tetap keberatan dapat mengajukan gugatan ke Pengadilan Negeri atas bukti-bukti lama tersebut.

Kata Kunci: Hukum Pertanahan; Hak atas tanah; Bukti lama kepemilikan hak atas tanah; Letter C Desa.
\end{abstract}




\section{Pendahuluan}

Bentuk bukti kepemilikan hak atas tanah di Indonesia sangat bermacammacam, hal ini terjadi karena Indonesia sendiri baru merdeka pada tahun 1945 dan baru memiliki hukum pertanahan nasional pada tahun 1960 yaitu UndangUndang Nomor 5 Tahun 1960 tentag Peraturan Dasar Pokok-Pokok Agraria yang lebih dikenal dengan Undang-Undang Pokok Agraria (UUPA). Sehingga masih sangat banyak bukti-bukti lama hak atas tanah yang masih digunakan sebagian masyarakat Indonesia. Dengan disahkannya UUPA tersebut maka berakibat hukum Indonesia tidak lagi tunduk pada hukum agraria kolonial dan digantikan dengan hukum agraria nasional. Hal ini berarti mencabut peraturanperaturan yang telah dibuat oleh pemerintah kolonial yaitu Agrarische Wer Stb. 1870 No. 55 yang termuat pada Pasal 51 IS Stb. 1925 No. 447, Koninklijk Belsuit (keputusan raja) tertanggal 16 April 1872 No. 29 (Stb. 1872 No. 117) serta peraturan pelaksanaannya, Peraturan tentang domein verklaring yang bersifat umum maupun khusus, dan Buku II KUH Perdata Indonesia yang mengatur mengenai bumi, air serta kekayaan alam yang terkandung di dalamnya, kecuali ketentuan-ketentuan tentang hypotheek yang masih berlaku pada UUPA. ${ }^{1}$

Terdapat beberapa prinsip dalam UUPA yang berkaitan dengan penelitian ini yang pertama adalah Prinsip Nasionalitas yang biasa disebut juga prinsip kebangsaan, prinsip tersebut mengandung makna bahwa seluruh wilayah Indonesia adalah karunia Tuhan yang Maha Esa serta kesatuan dan persatuan tanah air bangsa Indonesia, sehingga menjadi hak bagi bangsa Indonesia. ${ }^{2}$

Prinsip hak menguasai negara atas tanah juga digunakan dalam penelitian ini, prinsip tersebut bermakna bahwa negara bukanlah pemilik tanah melainkan menjadi organisasi tertinggi dari bangsa Indonesia yang diberi wewenang oleh Undang-Undang untuk melakukan pengaturan sesuai peraturan perundangundangan yang berlaku. Terminologi “dikuasai oleh negara” atau "Hak Menguasai Negara atas Tanah" yang dimaksudkan dalam UUPA memberi wewenang pada

\footnotetext{
1 Urip Santoso, Hukum Agraria Kajian Komprehensif (Prenadamedia Group 2012).[49].

2 Sri Hajati et al., Buku Ajar Politik Hukum Pertanahan (Airlangga University Press 2018 2018).[37].
} 
negara untuk mengatur, menentukan, dan menyelenggarakan hal-hal yang berkaitan dengan pemeliharaan bumi, air, dan luar angkasa, hubungan-hubungan hukum antara orang-orang dengan bumi, air, dan ruang angkasa, dan hubunganhubungan hukum antara orang-orang dan perbuatan-perbuatan hukum yang mengenai bumi, air, dan ruang angkasa. ${ }^{3}$

Ketiga adalah prinsip tanah memiliki fungsi sosial. Prinsip ini mempunyai arti bahwa tanah tidak semata-mata hanya untuk kepentingan pribadinya saja melainkan harus memperhatikan kepentingan masyarakat apalagi jika berpotensi menimbulkan kerugian bagi masyarakat. Akan tetapi aturan tersebut tidak serta merta bahwa kepentingan seseorang selalu terdesak oleh kepentingan umum. Kepentingan masyarakat dan kepentingan perseorangan haruslah seimbang, sehingga tujuan pokok yakni kemakmuran, keadilan, dan kebahagiaan bagi rakyat seluruhnya sebagaimana amanat ketentuan Pasal 2 ayat (3) UUPA dapat tercapai. ${ }^{4}$

\section{Keabsahan Bukti Lama Berupa Letter C Desa Dalam Kepemilikan Hak Atas} Tanah

Sejak 24 September 1960 Indonesia telah memiliki hukum agraria nasional sendiri yaitu UUPA. Oleh sebab itu seluruh bukti kepemilikan hak atas tanah yang ada sebelum UUPA harus disesuaikan dengan UUPA melalui proses pendaftaran tanah dan bukti kepemilikan hak atas tanah yang terbit setelah 24 September 1960 harus mengikuti apa yang telah diatur pada UUPA. Hal ini bertujuan untuk memberikan kepastian hukum dan perlindungan hukum bagi para pemegang hak atas suatu bidang tanah.

Pada Pasal 19 ayat (2) huruf c UUPA dinyatakan bahwa hasil yang diperoleh atas suatu kegiatan pendaftaran tanah adalah pemberian surat tanda bukti hak yang berguna sebagai alat pembuktian yang kuat akan tetapi pada Pasal tersebut belum dijelaskan surat tanda bukti kepemilikan hak atas tanah apa yang akan

\footnotetext{
3 Sri Winarsi, Kedudukan Badan Pertanahan Nasional Di Era Otonomi Daerah (Airlangga University Press 2018 2018).[49].

4 Sri Hajati et al. (n 2).et al., Op.Cit.[42].
} 
diberikan setelah kegiatan pendaftaran tanah. ${ }^{5}$ Bentuk surat bukti kepemilikan hak atas tanah yang akan diberikan setelah proses pendaftaran tanah baru disebutkan pada Pasal 13 ayat (3) PeraturanhPemerintah tentang Pendaftaran Tanah yang lama, pada Pasal tersebut dijelaskan bahwa surat tanda bukti kepemilikan hak atas tanah yang didaftarkan tersebut disebut dengan sertipikat. Ketentuan mengenai sertipikat tanah juga diperjelas pada Pasal 31 Peraturan PemerintahhNo. 24 Tahun 1997 tentang Pendaftaran Tanah. Kantor Pertanahan Kabupaten/Kota lah yang menerbitkan sertipikat tanah tersebut. ${ }^{6}$

Badan Pertanahan Nasional merupakan instansi yang menerbitkan sertipikat tanah, BPN sendiri merupakan Jabatan Tata Usaha Negara, sehingga berdasarkan Pasal 7 ayat (2) huruf a Undang-Undang No. 30 Tahun 2014 sertipikat yang diterbitkan tersebut merupakan Keputusan Tata Usaha Negara mengingat ketentuan pada Pasal 1 angka 9 Undang-Undang Nomor 51 Tahun 2009 tentang Perubahan Kedua Atas Undang-Undang Nomor 5 Tahun 1986 Tentang Peradilan Tata Usaha Negara. Apabila ada sengketa terhadap sertipikat hak atas tanah maka berdasar pada Pasal 53 Undang-Undang Nomor 9 Tahun 2004 tentang Perubahan Atas Undang-Undang Nomor 5 Tahun 1986 Tentang Peradilan Tata Usaha Negara, Pengadilan Tata Usaha Negara lah yang berwenang untuk memeriksa dan mengadili sengketa tersebut. ${ }^{7}$

Unsur KTUN harus ditetapkan oleh pejabat yang berwenang pada UndangUndang Administrasi Pemerintahan apabila dikaitkan dengan bukti kepemilikan hak atas tanah maka harus merujuk pada peraturan perundang-undangan yang memberikan wewenang suatu badan atau pejabat yang berwenang dalam menetapkan hak atas tanah. Pada UUPA belum ada ketentuan mengenai badan atau pejabat yang berwenang dalam urusan pertanahan, dalam Pasal 14 UUPA dikatakan pemerintahlah yang bertugas menyusun rencana persediaan,

5 ibid.,Op.Cit.[315].

6 ibid.[316].

7 Bung Pokrol, 'Sengketa Kepemilikan Tanah' (HukumOnline.com, 2005) <https://www.hukumonline.com/klinik/detail/ulasan/cl1210/sengketa-kepemilikan-tanah/> accessed 6 November 2019. 
peruntukan dan penggunaan bumi, air, dan ruang angkasa serta kekayaan alam yang terkandung didalamnya. ${ }^{8}$

Aturan mengenai badan atau pejabat yang berwenang dalam urusan pertanahan sendiri diatur pada Peraturan Menteri Agraria dan Tata Ruang/ Kepala Badan Pertanahan Nasional Nomor 8 Tahun 2015 tentang Organisasi dan Tata Kerja Kementerian Agraria dan Tata Ruang/Kepala Badan Pertanahan Nasional. Melalui Pasal 1 dan Pasal 2 pada Peraturan Menteri tersebut dijelaskan bahwa BPN merupakan lembaga pemerintah di bawah Presiden dan bertanggung jawab kepada Presiden yang mempunyai tugas melaksanakan tugas pemerintahan dalam bidang pertanahan baik secara nasional, regional, dan sektoral.

Pada Pasal 3 Peraturan Menteri tersebut juga dijelaskan bahwa BPN mempunyai fungsi untuk mengatur dan menetapkan kebijakan-kebijakan hak atas tanah. Sedangkan mengenai kewenangan yang dimiliki BPN sendiri pada dasarnya bersumber dari kewenangan yang melekat pada Presiden. ${ }^{9}$ Berdasarkan Pasal 2 ayat (1) huruf d Peraturan Menteri Agraria/Kepala Badan Pertanahan Nasional Nomor 3 Tahun 1999 tentang Pelimpahan Kewenangan Pemberian dan Pembatalan Pemberian Hak Atas Tanah Negara diatur bahwa wewenang pemberian hak atas tanah secara individual maupun kolektif serta pembatalan pemberian hak atas tanah sebagian dilimpahkan kepada BPN Provinsi atau Kepala Kantor Pertanahan Kabupaten/Kotamadya.

Pada Pasal 3 ayat (3) huruf $d$ peraturan tersebut diatur bahwa pemberian hak milik atas tanah dalam rangka pendaftaran tanah massal baik secara sistematik maupun sporadik menjadi kewenangan Kepala Kantor Pertanahan Kabupaten/ Kotamadya. Sehingga apabila dikaitkan dengan keabsahan bukti kepemilikan hak atas tanah berdasarkan peraturan perundang-undangan yang berlaku sekarang maka bukti kepemilikan hak atas tanah yang dikeluarkan oleh Kepala Desa berupa Letter C Desa bukan merupakan bukti kepemilikan hak atas tanah yang berlaku pada saat ini berdasarkan kewenangannya. Letter C Desa juga bukan merupakan

\footnotetext{
8 Sri Winarsi (n 3).Op.Cit.[61].

9 ibid.[71].
} 
alat bukti kepemilikan hak atas tanah yang kuat sesuai yang dimaksud pada Pasal 19 ayat (2) huruf c UUPA.

Dalam penetapan bukti kepemilikan hak atas tanah terdapat prosedurprosedur yang harus dilaksanakan oleh pemohon yaitu mekanisme pendaftaran tanah. Aturan mengenai pendaftaran tanah sendiri sebenarnya telah diatur pada Pasal 19 UUPA yang menyebutkan Pemerintah mengadakan pendaftaran tanah di seluruh wilayah Indonesia untuk menjamin kepastian hukum menurut ketentuan yang diatur dengan Peraturan Pemerintah.

Atas dasar Pasal 19 UUPA tersebut, lebih lanjut hal mengenai pendaftaran tanah diatur dengan Peraturan Pemerintah Nomor 10 Tahun 1961 tentang Pendaftaran Tanah. Akan tetapi Peraturan Pemerintah tersebut keberlakuannya dianggap belum efisien, selama 36 tahun aturan tersebut berlaku hanya kurang dari 30\% bidang tanah di Indonesia yang berhasil didaftarkan..$^{10}$ Oleh karenanya dalam rangka menunjang peningkatan dukungan yang lebih baik pada pembangunan nasional dengan memberikan kepastian hukum dalam bidang pertanahan, pemerintah memandang perlu dilakukannya penyempurnaan pada ketentuan-ketentuan yang diatur Peraturan Pemerintah Nomor 10 Tahun 1961 tentang Pendaftaran Tanah.

Atas pertimbangan tersebut, pada 8 Juli 1997 Pemerintah menerbitkan PeraturanmPemerintah Nomor 24 Tahun 1997 tentang Pendaftaran Tanah sebagai penyempurnaan dari PeraturanmPemerintah Nomor 10 Tahun 1961 tentang Pendaftaran Tanah tujuannya tetap sama yaitu memberikan jaminan kepastian hukum dibidang pertanahan. Dalam Pasal 5 PeraturanmPemerintah Nomor 24 Tahun 1997 diatur bahwa pendaftaran tanah diselenggarakan oleh Badan Pertanahan Nasional dan pada Pasal 13 PeraturanhPemerintah tersebut diatur bahwa penyelenggaraan pendaftaran tanah dilakukan secara sistematik dan sporadik.

Dalam pendaftaran tanah dilakukan secara sistematik maka berdasarkan Pasal 8 PeraturanmPemerintah Nomor 24 Tahun 1997 Kepala Kantor Pertanahan

${ }^{10}$ Sri Hajati et al. (n 2).et al., Op.Cit.[284]. 
akan dibantu oleh panitia ajudikasi yang dibentuk oleh menteri atau pejabat yang ditunjuk. Ketua panitia ajudikasi merangkap anggota merupakan jabatan yang dijabat oleh seorang pegawai Badan Pertanahan Nasional. Pada Pasal 13 ayat (2) PeraturanmPemerintah Nomor 24 Tahun 1997 wilayah-wilayah yang dilakukan pendaftaran tanah secara sistematik adalah wilayah-wilayah yang telah didasarkan pada suatu rencana kerja dan ditetapkan oleh menteri. Pendaftaran dengan cara sistematik ini merupakan cara pendaftaran yang diutamakan karena dengan cara sistematik ini dapat mempercepat perolehan data mengenai bidang-bidang tanah yang akan didaftarkan apabila dibandingkan dengan cara sporadik. ${ }^{11}$

Sedangkan dalam pendaftaran tanah secara sporadik maka sesuai Pasal 13 ayat (3) PeraturanhPemerintah Nomor 24 Tahun 1997 pihak yang berkepentingan lah yang mengajukan permohonan untuk pendaftaran tanah miliknya. Pelaksanaan kegiatan pendaftaran tanah secara sporadik juga akan dimaksimalkan, hal ini diperlukan karena pada kenyataannya semakin banyak permintaan untuk mendaftar secara individual dan massal yang diperlukan untuk pelaksanaan pembangunan. ${ }^{12}$

Dalam pelaksanaan kegiatannya tidak ada perbedaan antara pendaftaran tanah secara sistematik maupun sporadik. Kedua cara pendaftaran tanah tersebut diatur dalam Pasal 12 ayat (1) Peraturan PemerintahhNomor 24 Tahun 1997 yaitu diawali dengan pengumpulan dan pengolahan data fisik, terdapat serangkaian kegiatan dalam pengumpulan dan pengolahan data fisik ini yang diawali dengan pembuatan peta dasar pendaftaran. Sesuai pada Pasal 16 PeraturanhPemerintah Nomor 24 Tahun 1997 bahwa BPN yang akan menyelenggarakan pemasangan, pengukuran, pemetaan dan pemeliharaan titik-titik dasar teknik nasional di setiap Kabupaten/Kota. Kemudian dilanjutkan dengan penetapan batas bidang-bidang tanah sebagaimana diatur pada Pasal 17 Peraturan Pemerintah Nomor 24 Tahun 1997 hal ini bertujuan untuk memperoleh data fisik yang diperlukan untuk kegiatan pendaftaran tanah yang meliputi keterangan mengenai letak, batas, luas bidang tanah serta keterangan mengenai bangunan atau bagian bangunan di atasnya.

\footnotetext{
11 ibid.[286].

12 ibid.[286].
} 
Selanjutnya dilakukan proses pengukuran dan pemetaan bidang-bidang tanah dan pembuatan peta pendaftaran dengan memperhatikan ketentuan-ketentuan yang ada pada Pasal 20 Peraturan PemerintahhNomor 24 Tahun 1997.

Kegiatan pengumpulan dan pengolahan data fisik diakhiri dengan pembuatan daftar tanah dan pembuatan surat ukur sesuai ketentuan pada Pasal 21 dan Pasal 22 PeraraturanmPemerintah Nomor 24 Tahun 1997. Merujuk pada ketentuan tersebut, dalam hal pembuatan surat ukur dalam pendaftaran tanah secara sporadik yang belum tersedia peta pendaftaran surat ukur dibuat berdasarkan pengukuran yang dilakukan sesuai ketentuan pada Pasal 20 PeraturanhPemerintah Nomor 24 Tahun 1997.

Apabila pengumpulan dan pengolahan data dalam pendaftaran tanah untuk pertama kali telah terpenuhi maka proses pendaftaran tanah dilanjutkan dengan pembuktian hak dan pembukuannya. Secara umum dalam pembuktian hak dibedakan menjadi dua, yaitu pembuktian hak baru dan pembuktian hak lama. ${ }^{13}$ Dalam hal pembuktian hak baru perlu merujuk pada Pasal 23 PeraturanmPemerintah Nomor 24 Tahun 1997 dan dalam hal pembuktian hak lama ketentuannya diatur pada Pasal 24 PeraturanbPemerintah Nomor 24 Tahun 1997 untuk bentuk-bentuk bukti hak lama yang dapat diajukan untuk pendaftaran tanah dijelaskan pada bagian Pasal 24 ayat (1) Penjelasan PeraturanhPemerintah Nomor 24 Tahun 1997. Apabila bukti tertulis tidak lengkap atau tidak ada lagi, dalam pembuktiannya dapat dilakukan dengan keterangan saksi atau pernyataan yang bersangkutan yang kebenarannya dapat dipercaya oleh panitia ajudikasi dalam hal pendaftaran tanah secara sistematik dan kepala kantor pertanahan dalam hal pendaftaran tanah dilakukan secara sporadik. ${ }^{14}$ Apabila proses pembuktian hak telah diselesaikan maka selanjutnya adalah proses penerbitan sertipikat.

Proses penerbitan sertipikat sendiri diatur pada Pasal 31 Peraturan PemerintahgNomor 24 Tahun 1997. Sertipikat sendiri diterbitkan untuk kepentingan pemegang hak yang bersangkutan sesuai dengan data fisik dan juga

\footnotetext{
13 ibid.[307].

14 ibid.[308].
} 
data yuridis yang telah terdaftar dalam buku tanah. Apabila terdapat sebidang tanah yang telah diterbitkan sertipikat secara sah dan atas nama orang ataupun badan hukum yang memperoleh tanah dengan itikad baik dan menguasainya secara nyata maka apabila ada pihak lain yang merasa mempunyai hak atas tanah itu tidak dapat lagi menuntut pelaksanaan hak tersebut apabila dalam 5 tahun setelah diterbitkannya sertipikat tersebut tidak mengajukan keberatan kepada pemegang sertipikat dan kepala kantor pertanahan yang bersangkutan secara tertulis ataupun mengajukan gugatan ke Pengadilan atas hal tersebut. ${ }^{15}$ Dilanjutkan oleh proses penyajian data fisik dan data yuridis

Penyajian data fisik dan data yuridis sendiri diatur pada Pasal 33 PeraturanmPemerintah Nomor 24 Tahun 1997. Pada Pasal tersebut diatur bahwa kantor pertanahan menyelenggarakan tata usaha pendaftaran tanah dalam daftar umum yang meliputi peta pendaftaran, daftar tanah, surat ukur, buku tanah, dan daftar nama. Dalam hal penyajian data fisik dan data yuridis sesuai yang diatur pada Pasal 34 PeraturanmPemerintah Nomor 24 Tahun 1997 setiap orang yang memiliki kepentingan berhak untuk mengetahui data fisik dan data yuridis yang tersimpan dalam peta pendaftaran, daftar tanah, surat ukur, dan buku tanah sedangkan baik data fisik maupun yuridis yang tercantum pada daftar nama hanya terbuka bagi instansi-instansi tertentu untuk kepentingan pelaksanaan tugas. Proses pendaftaran tanah untuk pertama kali diakhiri dengan proses penyajian/ penyimpanan data umum dan dokumen.

Mengenai hal penyimpanan data umum dan dokumen diatur pada Pasal 35 PeraturanmPemerintah Nomor 24 Tahun 1997 dalam Pasal tersebut diatur bahwa segala dokumen yang merupakan alat pembuktian yang telah digunakan sebagai dasar dalam pendaftaran tanah disimpan di kantor pertanahan atau di tempat lain yang telah ditetapkan oleh menteri akan tetapi apabila ada instansi yang memerlukannya dapat meminta izin tertulis kepada pejabat yang ditunjuk untuk diberikan salinan bukti tersebut.

15 ibid.[309]. 
Serangkaian kegiatan di atas merupakan prosedur yang harus dilalui dalam pendaftaran tanah untuk pertama kali sesuai peraturan perundang-undangan yang berlaku yaitu Peraturan Pemerintah Nomor 24 Tahun 1997 tentang Pendaftaran Tanah. Apabila pendaftaran tanah yang dilakukan telah memenuhi seluruh persyaratan yang diatur pada Peraturan Pemerintah tersebut maka dapat dikatakan bahwa kegiatan pendaftaran tanah yang dilakukan adalah proses pendaftaran tanah yang sah dan mempunyai kedudukan hukum dalam prosesnya sehingga hasil dari proses pendaftaran tanah tersebut merupakan hasil yang sah.

Penjelasan atas paragraf diatas memiliki arti bahwa bukti berupa surat Letter CDesa yang diterbitkan oleh Kepala Desa tersebut tidak memenuhi salah satu unsur keabsahan sebagaimana diatur pada Pasal 52 ayat (1) huruf b Undang-Undang Nomor 30 Tahun 2014 tentang Administrasi Pemerintahan yang mensyaratkan suatu ketetapan dapat dikatakan sah apabila dibuat sesuai prosedur. Sedangkan proses pendaftaran tanah yang diatur oleh Peraturan Pemerintah Nomor 24 Tahun 1997 dapat dimaknai sebagai "sesuai prosedur" yang berlaku dalam penerbitan suatu bukti kepemilikan hak atas tanah.

Substansi yang sesuai dengan objek keputusan berdasarkan Pasal 52 ayat (1) huruf c merupakan salah satu kriteria yang harus dipenuhi dalam syarat sahnya suatu keputusan. Hal ini berkaitan dengan pembahasan di atas mengenai wewenang dan prosedur dalam penetapan bukti kepemilkan hak atas tanah.

Objek pendaftaran tanah memiliki arti yaitu bidang-bidang tanah yang dapat didaftarkan baik yang telah dilekati hak maupun belum. ${ }^{16}$ untuk mengetahui macam-macam objek yang dapat didaftarkan perlu merujuk pada Pasal 9 ayat (1) Peraturan Pemerintah Nomor 24 Tahun 1997 tentang Pendaftaran tanah, pada huruf a hingga huruf $\mathrm{f}$ Pasal tersebut diatur mengenai objek apa saja yang dapat dijadikan objek pendaftaran tanah. Yaitu bidang tanah dengan hak milik, hak guna usaha, hak guna bangunan, hak pakai, tanah hak pengelolaan, tanah wakaf, hak milik atas satuan rumah susun, hak tanggungan, dan tanah negara.

16 Waskito dan Hadi Arnowo, Penyelenggaraan Pendaftaran Tanah di Indonesia (Prenadamedia Group 2019).[57]. 
Sedangkan UUPA sendiri hanya mengatur apa yang ada pada huruf a Peraturan Pemerintah tersebut yaitu mengenai hak milik pada Pasal 23, hak guna usaha pada Pasal 32, hak guna bangunan pada Pasal 38, dan hak pakai pada Pasal 41 Undang-Undang No. 5 Tahun $1960 .{ }^{17}$ Objek-objek sesuai yang diatur pada UUPA maupun pada Peraturan Pemerintah No. 24 Tahun 1997 itulah merupakan objek yang dapat diterbitkan sertipikat dan menjadi alat bukti kepemilikan tanah yang kuat sebagaimana diatur pada Pasal 32 Peraturan Pemerintah No. 24 Tahun 1997.

Dalam penelitian ini yang menjadi alat bukti kepemilikam hak atas tanah adalah Letter CDesa. Letter CDesa sendiri tidak termasuksebagai objek pendaftaran tanah sebagaimana diatur pada Pasal 9 Peraturan Pemerintah Nomor 24 Tahun 1997. Sehingga berdasarkan Pasal tersebut dapat disimpulkan bahwa Letter C Desa merupakan salah satu bentuk bukti kepemilikan hak atas tanah yang belum didaftarkan baik secara sistematis ataupun secara sporadik berdasarkan Pasal 19 Undang-Undang No. 5 Tahun 1960 jo. Pasal 9 ayat (1) Peraturan Pemerintah No. 24 Tahun 1997. Berdasarkan pada aturan-aturan tersebut dapat disimpulkan bahwa Letter C Desa bukan merupakan objek penetapan pendaftaran hak atas tanah dan oleh karenanya tidak memenuhi unsur ketiga sahnya suatu keputusan yang diatur pada Pasal 52 ayat (1) huruf c Undang-Undang Nomor 30 Tahun 2014 tentang Administrasi Pemerintahan.

Ketiga sub-sub bab diatas menjelaskan mengenai keabsahan bukti kepemilikan hak atas tanah setelah berlakunya hukum agraria nasional yaitu Undang-Undang No. 5 Tahun 1960 jo. Peraturan Pemerintah No. 24 Tahun 1997 tentang Pendaftaran Tanah dengan ketentuan yang disyaratkan oleh Pasal 52 ayat (1) Undang-Undang No. 30 Tahun 2014 tentang Administrasi Negara yaitu berdasarkan wewenang, prosedur, dan substansi yang sesuai dengan objek keputusan.

Melalui analisa dari beberapa peraturan perundang-undangan yang berkaitan dengan wewenang, prosedur, dan substansi yang sesuai dengan objek keputusan dalam penerbitan bukti kepemilikan hak atas tanah setelah berlakunya

${ }^{17}$ Santoso (n 1)., Op.Cit.[298]. 
hukum agraria nasional maka apabila dikaitkan pada penelitian ini dapat disimpulkan bahwa bukti kepemilikan hak atas tanah pada penelitian ini yaitu Letter C Desa yang diterbitkan oleh Kepala Desa bukan merupakan alat bukti kepemilikan hak atas tanah yang berlaku setelah adanya hukum agraria nasional.

Berdasarkan Pasal 1 angka 3 Undang-Undang Nomor 5 Tahun 1986 yang dimaksud Keputusan Tata Usaha Negara adalah suatu penetapan tertulis yang dikeluarkan oleh badan maupun pejabat tata usaha negara yang berwenang serta berisi tindakan hukum tata usaha negara yang didasarkan pada peraturan perundang-undangan yang berlaku, yang sifatnya konkret, individual, dan final, yang menimbulkan akibat hukum baik bagi seseorang maupun badan hukum perdata.

Penetapan tertulis sendiri memiliki artian bahwa cukup hanya dengan adanya hitam di atas putih karena pada penjelasan Pasal tersebut nota ataupun memo saja telah memenuhi syarat penetapan tertulis tanpa perlu adanya blangko. ${ }^{18}$ Apabila dikaitkan dengan permasalahan dalam penelitian ini yaitu bukti lama hak atas tanah berupa Letter C Desa maka surat tersebut dapat digolongkan sebagai penetapan tertulis karena bentuk fisik dari letter c sendiri adalah serangkaian pencatatan pembukuan sehingga dalam kaitannyaa dengan KTUN maka surat Letter C Desa telah memenuhi unsur penetapan tertulis.

Letter C Desa sendiri merupakan suatu penetapan tertulis yang diterbitkan oleh Lurah atau Kepala Desa. Pejabat atau badan tata usaha negara yang dimaksud sebagaimana diatur pada Pasal 1 angka 2 Undang-Undang Nomor 5 Tahun 1986 pada dasarnya adalah badan atau pejabat yang melakukan urusan pemerintahan, ${ }^{19}$ sedangkan berdasarkan Pasal 1 angka 3 Undang-Undang Nomor 6 Tahun 2014 tentang Desa dikatakan bahwa Kepala Desa adalah pejabat yang memiliki fungsi menyelenggarakan urusan pemerintahan ditingkat desa. Sehingga surat Letter C yang diterbitkan oleh Kepala Desa tersebut telah memenuhi salah satu elemen KTUN yaitu dibuat oleh badan atau pejabat tata usaha negara.

${ }_{18}$ Philipus M. Hadjon et al., Pengantar Hukum Administrasi Indonesia (Gadja Mada University Press 2015)...[133].

19 ibid.[133]. 
Elemen yang melekat pada KTUN yang lainnya adalah bersifat konkret, individual, dan final. Dalam hal ini jelas yang ditetapkan oleh Kepala Desa adalah surat Letter C Desa sehingga dapat dikatakan konkret, pada surat Letter C Desa yang tersebut tertulis dengan jelas nama seseorang tertentu, dan sifat final pada surat Letter $C$ tersebut terdapat pada tidak diperlukannya persetujuan dari badan maupun pejabat tata usaha negara lain dalam penerbitannya sehingga surat Letter C Desa tersebut telah memenuhi elemen pada KTUN yaitu bersifat konkret, individual, dan final.

Elemen terakir pada KTUN yang harus dipenuhi ialah menimbulkan akibat hukum bagi seseorang ataupun badan hukum. Hal ini memiliki konsekuensi bahwa penggugat haruslah seseorang ataupun badan hukum. ${ }^{20}$ Dalam kaitannya dengan Letter C Desa apabila terjadi suatu permasalahan maka badan atau pejabat tata usaha negara dalam hal ini Kepala Desa tidak dimungkinkan untuk menggugat badan atau pejabat tata usaha negara lainnya sebagai pihak ketiga yang berkepentingan. Dengan telah terpenuhinya elemen-elemen KTUN pada bukti lama hak atas tanah berupa Letter C Desa sesuai dengan yang terkandung dalam Undang-Undang Nomor 5 Tahun 1986 maka Letter C Desa dapat digolongkan sebagai KTUN.

Sejak tahun 1960 hukum pertanahan yang berlaku di Indonesia adalah hukum pertanahan sebagaimana diatur pada UUPA, sehingga seluruh kegiatan yang berhubungan dengan agraria maupun pertanahan harus didasarkan pada UUPA. Pada UUPA sendiri tidak ada satu Pasal pun yang menjelaskan tentang Letter C Desa. Akan tetapi Letter C Desa tergolong dalam bukti lama hak atas tanah yang keberlakuannya harus didaftarkan terlebih dahulu berdasarkan Peraturan Pemerintah No. 24 Tahun 1997 tentang Pendaftaran Tanah.

Berdasarkan Pasal 24 Peraturan Pemerintah No. 24 Tahun 1997 diatur mengenai pembuktian hak lama, yaitu hak atas tanah yang berasal dari konversi hak-hak lama yang harus dibuktikan dengan alat-alat bukti lainnya mengenai

20 ibid.[135]. 
adanya hak tersebut berupa bukti-bukti tertulis, keterangan saksi, dan/atau pernyataan oleh yang bersangkutan. Pada bagian penjelasan Pasal tersebut disebutkan macam-macam bukti lama kepemilikan hak atas tanah yang dapat digunakan dalam kegiatan pendaftaran tanah, pada bagian penjelasan tersebut tidak disebutkan bukti lama berupa Letter C Desa. Akan tetapi pada bagian penjelasan Pasal 24 ayat (1) huruf k Peraturan Pemerintah No.24 Tahun 1997 tentang Pendaftaran Tanah disebutkan bentuk-bentuk yang dapat dijadikan bukti tertulis antara lain Petuk Pajak Bumi/Landrente, girik, pipil, kekitir, dan verponding Indonesia sebelum berlakunya Peraturan Pemerintah No. 10 Tahun 1961 tentang Pendaftaran Tanah.

Letter C Desa yang ditetapkan oleh Kepala Desa dalam Pasal tersebut tergolong pada Verponding Indonesia sehingga Letter C Desa juga merupakan alat bukti dalam melakukan konversi ${ }^{21}$ sesuai yang diatur oleh Pasal 3 Peraturan Menteri Pertanian dan Agraria No. 2 Tahun 1962 tentang Pengesahan Konversi dan Pendaftaran Bekas Hak-Hak Indonesia Atas Tanah yang mengatur bahwa permohonan untuk penegasan mengenai hak-hak yang tidak diuraikan didalam sesuatu surat hak tanah diajukan kepada Kepala Kantor Pendaftaran Tanah yang bersangkutan disertai tanda bukti haknya yaitu surat pajak hasil bumi/verponding Indonesia ataupun bukti surat pemberian hak oleh instansi yang berwenang. Serta dapat mengajukan surat keterangan Kepala Desa yang membenarkan surat tanda bukti hak tersebut, menerangkan apakah tanahnya perumahan atau pertanian dan juga menerangkan siapa seseorang yang memiliki hak tersebut disertai turunan surat/surat jual-beli tanahnya apabila ada. Aturan mengenai surat keterangan Kepala Desa tersebut dapat dimaknai sebagai Letter C Desa.

Hal tersebut diperkuat oleh surat Keputusan Menteri Dalam Negeri No. Sk. 26/DDA/1970 tentang Penegasan Konversi Pendaftaran Bekas Hak-Hak Indonesia Atas Tanah yang menegaskan yang dianggap sebagai “tanda bukti hak" pada Pasal 3 Peraturan Menteri Pertanian dan Agraria No. 2 Tahun 1962. Huruf

${ }^{21}$ Reynaldi A. Dilapanga, 'Kedudukan Hukum Registrasi Desa (LETTER C) Dalam Pembuktian Hak Milik Atas Tanah Menurut UUPA No. 5 Tahun 1960’ (1960) 4 Lex Administratum.[171]. 
b surat tersebut menyatakan bahwa surat-surat asli jual beli, hibah dan/atau tukar menukar yang dibuat dihadapan Kepala Desa yang bersangkutan sebelum diselenggarakannya pendaftaran tanah menurut Peraturan Pemerintah No. 10 Tahun 1961 di daerah-daerah yang hingga tanggal 24 September 1960 masih belum dipungut pajak hasil bumi/verponding Indonesia dapat dianggap sebagai "tanda bukti hak".

Sehingga atas analisa diatas dapat disimpulkan bahwa Letter C Desa merupakan alat bukti kepemilikan hak atas tanah yang sah sebagai alat bukti tertulis pada pembuktian hak lama atas tanah dalam kegiatan pendaftaran tanah sesuai yang diatur oleh Peraturan Pemerintah No.10 Tahun 1961 Jo. Peraturan Pemerintah No. 24 Tahun 1997 tentang Pendaftaran Tanah. Akan tetapi memang Letter C Desa bukan merupakan alat bukti kepemilikan hak atas tanah yang kuat layaknya sertipikat tanah.

\section{Perlindungan Hukum Bagi Pemegang Bukti Lama Berupa Letter C Desa Dalam Kepemilkan Hak Atas Tanah}

Tujuan utama dari pendaftaran tanah sebagaimana yang ditetapkan dalam Pasal 3 Peraturan Pemerintah No. 24 Tahun 1997 adalah untuk menjamin dan memberikan kepastian hukum serta perlindungan hukum bagi pemegang hak atas suatu bidang tanah, satuan rumah susun, dan hak-hak lainnya yang mempermudah bagi para pemegang hak tersebut untuk membuktikan kepemilikannya. ${ }^{22}$ Bagi pihak yang memegang hak tersebut diberikan sertipikat hak atas tanah.

Aturan mengenai sertipikat sendiri telah ada pada Pasal 19 ayat (2) UUPA yang menyatakan bahwa akhir dari kegiatan pendaftaran tanah adalah surat tanda bukti hak yang berlaku sebagai alat pembuktian yang kuat, akan tetapi pada Pasal tersebut tidak disebutkan nama dari surat tanda bukti hak yang dapat berlaku sebagai alat pembuktian. Barulah pada Pasal 13 ayat (3) Peraturan Pemerintah No. 10 Tahun 1961 surat tanda bukti sebagaimana diatur pada Pasal 19 ayat (2) UUPA

${ }^{22}$ Santoso (n 1)., Op.cit.[315]. 
tersebut dinamakan sebagai sertipikat yang isinya adalah salinan buku tanah dan surat ukur yang dijahit menjadi satu dengan sampul yang bentuknya ditetapkan oleh Menteri Agraria.

Bukti-bukti tertulis sebagaimana disebutkan dalam bagian penjelasan Pasal 24 ayat (1) huruf a-m Peraturan Pemerintah No.24 Tahun 1997 tentang Pendaftaran Tanah berdasarkan Pasal 25 ayat (1) Peraturan Pemerintah No. 24 Tahun 1997 dikumpulkan kepada panitia ajudikasi dalam hal pendaftaran dilakukan secara sistematik dan dikumpulkan kepada Kepala Kantor Pertanahan dalam hal pendaftaran tanah dilakukan secara sporadik untuk menilai kebenaran materiil maupun formil dari alat bukti tertulis yang diserahkan tersebut. Lalu pada ayat (2) Pasal tersebut dijelaskan bahwa hasil dari alat-alat bukti yang telah diteliti kebenarannya tersebut dituangkan dalam suatu daftar isianyyang ditetapkan oleh Menteri.

Selanjutnya pada Pasal 26 Peraturan Pemerintah No. 24 Tahun 1997 diatur bahwa daftar isian sebagaimana dimaksud pada Pasal 25 ayat (2) serta peta bidang dan/atau bidang-bidang tanah yang bersangkutanmsebagai hasil pengukuran harus diumumkan selama 30 (tiga puluh) hari di Kantor Panitia Ajudikasi apabila pendaftaran tanah dilakukan dengan cara sistematik dan selama 60 (enam puluh) hari di Kantor Kepala Desa/Kelurahan yang bersangkutan apabila pendaftaran tanah dilakukan dengan cara sporadik serta dapat dilakukan melalui media massa apabila pendaftaran tanah dilakukan secara sporadik individual untuk memberi kesempatan apabila ada pihak yang mengajukan keberatan atas daftar isian tersebut.

Apabila dalam jangka waktu yang telah ditentukan tersebut ada pihak yang mengajukan keberatan atas daftar isian yang diumumkan tersebut berdasarkan Pasal 27 Peraturan Pemerintah No. 24 Tahun 1997 maka Ketua Panitia Ajudikasi dalam pendaftaran secara sistematik dan Kepala Kantor Pertanahan dalam pendaftaran secara sporadik agar mengusahakan keberatan yang diajukan oleh pihak yang bersangkutan sesegera mungkin dalam jangka waktu sebagaimana diatur pada Pasal 26 Peraturan Pemerintah tersebut yaitu 30 (tiga puluh) hari dalam pendaftaran sistematis dan 60 (enam puluh) hari dalam pendaftaran secara 
sporadik diselesaikan secara musyawarah mufakat, hasil dari musyawarah mufakat tersebut dituangkan dalam berita acara penyelesaian dan apabila musyawarah tersebut menyebabkan berubahnya data daftar isian maka perubahan tersebut diumumkan kembali seperti yang diatur pada Pasal 26 Peraturan Pemerintah No. 24 Tahun 1997.

Namun jika musyawarah tersebut tidak berhasil maka berdasarkan ketentuan Pasal 27 ayat (3) Peraturan Pemerintah No. 24 Tahun 1997 Ketua Panitia Ajudikasi dalam pendaftaran secara sistematik dan Kepala Kantor Pertanahan dalam pendaftaran secara sporadik memberitahukan kepada pihak yang mengajukan keberatan secara tertulis agar mengajukan gugatan mengenai data fisik dan/atau data yuridis kepada Pengadilan. Dalam hal yang menjadi permasalahan adalah adanya tumpang tindih alat bukti tertulis pendaftaran tanah maka mengingat ketentuan Pasal 24 ayat (1) Peraturan Pemerintah No. 24 Tahun 1997 yang menyatakan bahwa bukti-bukti sebagaimana dicantumkan dibagian penjelasan huruf a s.d. m Pasal tersebut sifatnya merupakan alat bukti tertulis. maka apabila ada sengketa dalam hal ini pengadilan yang memiliki kompetensi absolut atas permasalahan ini adalah Pengadilan Negeri.

Pada ketentuan Pasal 31 ayat (1) \& (3) Peraturan Pemerintah No. 24 Tahun 1997 menyatakan bahwa sertipikat hanya diterbitkan untuk kepentingan pemegang hak yang bersangkutan sesuai dengan data fisik dan data yuridis yang telah terdaftar pada buku tanah dan sertipikat tersebut hanya boleh diserahkan kepada pihak yang identitasnya tercantum dalam buku tanah yang bersangkutan sebagai pemegang hak atau kepada pihak yang lain atas kuasa dari yang bersangkutan.

Berdasarkan Pasal 32 ayat (1) Peraturan Pemerintah No. 24 Tahun 1997 sertipikat merupakan surat tanda bukti hak yang berlaku sebagai alat pembuktian yang kuat mengenai data fisik dan data yuridis yang termuat didalamnya sepanjang data tersebut telah sesuai dengan datahyang adahdalam surat ukur dan buku tanah hak yang bersangkutan. Akan tetapi terdapat kelemahan pada ketentuan Pasal 32 ayat (1) Peraturan Pemerintah No. 24 Tahun 1997 yaitu kebenaran data fisik dan data yuridis tidak dijamin oleh negara serta tidak ada 
jaminan bagi pemilik sertipikat karena sewaktu-waktu dapat digugat oleh pihak lain yang merasa dirugikan atas terbitnya sertipikat tersebut. ${ }^{23}$

Perlindungan hukum terhadap sertipikathyang diterbitkan atas konversi bukti-bukti lama termasuk Letter C Desa sendiri diatur pada Pasal 32 ayat (2) Peraturan Pemerintah No. 24 Tahun 1997 yang menyatakan bahwa apabila suatu bidang tanah telah diterbitkan sertipikathsecara sah atas nama orang atau badan hukum yang memperoleh tanah tersebut dengan itikad baik danhsecara nyata menguasainya, maka apabila ada pihak lain yang merasa mempunyai hak atas tanah itu tidak dapat lagi menuntut pelaksanaanHhak tersebut apabila dalam waktu 5 (lima) tahun sejak diterbitkannya sertipikat itu tidak mengajukan keberatan secara tertulis kepada pemegang sertipikat dan KepalahKantor Pertanahan yang bersangkutan ataupun tidak mengajukan gugatan ke Pengadilan mengenai penguasaan tanah atauHpenerbitan sertipikat. Dengan adanya aturan-aturan tersebut maka dapat disimpulkan bahwa sertipikat bersifat mutlak sebagai surat tanda bukti hak apabila telah memenuhi unsurunsur sebagai berikut secara kumulatif: ${ }^{24}$

a. Sertipikat diterbitkan secara sah atas nama orang atau badan hukum

Kata diterbitkan secara sah memiliki arti sertipikat yang diterbitkan harus memperhatikan syarat keabsahan pada ketentuan Pasal 52 ayat (2) Undang-Undang No. 30 Tahun 2014 tentang Administrasi Pemerintahan yaitu weweng, prosedur, dan substansi yang sesuai dengan objek Keputusan sebagaimana telah dijelaskan pada sub Bab 2.1 penelitian ini.

Sedangkan kata atas nama orang atau badan hukum mempunyai arti bahwa suatu sertipikat yang diterbitkan secara sah oleh instansi yang berwenang harus mencantumkan pada sertipikat tersebut identitas pemegang hak tersebut baik individual maupun badan hukum sesuai dengan data yuridis yang ada. Mengingat ketentuan pada Pasal 31 ayat (3) Peraturan Pemerintah No. 24 Tahun 1997 yang mensyaratkan bahwa hanya

\footnotetext{
23 ibid.[319].

24 ibid.[319].
} 
pihak yang namanya tercantum dalam sertipikat lah yang dapat menerima sertipikat tersebut atau pihak lain atas kuasa olehnya.

b. Tanah diperoleh dengan itikad baik

Sertipikat hak milik atas tanah diterbitkan atas dasar permohonan pemegang hak yang beritikad baik atas obyek tanah tersebut serta tidak terdapat tipu muslihat dalam perolehannya. Berdasarkan KBBI pengertian itikad baik adalah kepercayaan, keyakinan yang teguh, kemauan yang baik. ${ }^{25}$ Itikad baik dapat dibedakan sifatnya yang subjektif yaitu seseorang memperhatikan sikap dan tingkah laku yang nyata dari subjek itu sendiri. Sedangkan pada itikad baik yang objektif atau hal yang sesuai dengan akal sehat dan pikiran dibuat dengan ukuran objektif dalam menilai keadaan sekitar perbuatan hukumnya. ${ }^{26}$

c. Tanah dikuasai secara nyata

Tidak ada ketentuan yang mengatur tentang hal ini apabila telah diterbitkan sertipikat atas tanah tersebut. Namun apabila kaitannya dengan kegiatan pendaftaran tanah untuk pertama kali diatur pada ketentuan Pasal 24 ayat (2) Peraturan Pemerintah No. 24 Tahun 1997 yang apabila dalam hal tidak ada lagi alat-alat pembuktian sebagaimana dijelaskan pada ayat sebelumnya maka pembukuan hak dapat dilakukan oleh pemohon dengan membuktikan penguasaan fisik bidang tanah yang bersangkutan selama 20 (dua puluh) tahun atau lebih secara berturut-turut. Penguasaan tersebut harus dilakukan dengan itikad baik danjuga diperkuat kesaksian orang yang dapat dipercaya.

d. Dalam waktu 5 (lima) tahun sejak diterbitkannya sertipikat tidak ada pihak yang mengajukan kebertan secara tertulis ataupun gugatan mengenai penguasaan tanah atau penerbitan sertipikat.

\footnotetext{
${ }^{25}$ KBBI, 'KBBI, “Itikad Baik”, (KBBI 2019)’ (2019).

${ }^{26}$ Sahnan Dadi Arja Kusuma dan Rodliyah, 'Sertifikat Hak Milik Atas Tanah Sebagai Alat Bukti Hak Yang Kuat' (2017) 5 Jurnal IUS.[313].
} 
Seperti yang telah dijelaskan diatas mengenai hal ini diatur pada ketentuan Pasal 32 ayat (2) Peraturan Pemerintah No. 24 Tahun 1997 yang tujuannya adalah memberikan perlindungan hukum bagi pemegang sertipikat yang telah memenuhi unsur-unsur pada poin a-c sebagaimana telah dijelaskan diatas.

Sehingga dapat disimpulkan bahwa perlindungan hukum suatu bukti lama kepemilikan hak atas tanah yang dalam penelitian ini adalah Letter C Desa telah melalui serangkaian kegiatan pendaftaran tanah secara sah dan dilakukan dengan itikad baik yang pada akhirnya menghasilkan sertipikat Hak Milik Atas Tanah dan dalam waktu 5 (lima) tahun setelah terbitnya sertipikat tersebut tidak ada satupun pihak yang mengajukan keberatan secara tertulis kepada pemegang sertipikat maupun Kepala Kantor Pertanahan yang bersangkutan ataupun tidak mengajukan gugatan ke Pengadilan maka mengacu pada ketentuan-ketentuan yang ada pada Peraturan Pemerintah No. 24 Tahun 1997 tentang Pendaftaran Tanah, sertipikat tersebut berlaku sebagai alat pembuktian yang kuat mengenai data fisik dan data yuridis serta apabila ada pihak lain yang merasa mempunyai hak atas tanah tersebut tidak dapat lagi menuntut pelaksanaan hak tersebut.

\section{Kesimpulan}

Dalam hal keabsahan bukti kepemilikan hak atas tanah setelah adanya UUPA maka perlu memperhatikan ketentuan Pasal 19 ayat (2) huruf c UUPA yang menyatakan bahwa akhir dari kegiatan pendaftaran tanah sesuai aturan Peraturan Pemerintah No. 24 Tahun 1997 tentang Pendaftaran tanah adalah pemberian surat-surat tanda bukti hak yang berlaku sebagai alat pembuktian yang kuat yang disebut dengan sertipikat. Sedangkan mengenai keabsahan Letter C Desa sendiri sebagai bukti kepemilikan hak atas tanah diatur pada Pasal 24 ayat (1) Peraturan Pemerintah No. 24 Tahun 1997, Letter C Desa merupakan alat pembuktian tertulis yang dapat digunakan dalam kegiatan pendaftaran tanah melalui pembuktian hak lama sebagaimana dijelaskan di huruf $\mathrm{k}$ bagian penjelasan Pasal 24 ayat (1) Peraturan Pemerintah No. 24 Tahun 1997. Sedangkan dalam hal perlindungan hukum pemegang hak atas tanah kekuatan alat bukti 
kepemilikan hak atas tanah berupa sertipikat ini diperkuat lagi oleh ketentuan yang ada pada Pasal 32 ayat (2) Peraturan Pemerintah No. 24 Tahun 1997 yang menyatakan bahwa apabila sertipikat telah terbit lebih dari 5 (lima) tahun maka bila ada pihak yang merasa keberatan atas terbitnya sertipikat tersebut sudah tidak dapat menuntut pelaksanaan atas hak tersebut. Sedangkan bukti lama berupa Letter C Desa sendiri juga dilindungi sebagaimana diatur pada Pasal 24 ayat (1) Peraturan Pemerintah No. 24 Tahun 1997 akan tetapi hanya sebatas alat bukti tertulis saja masih diperlukan tambahan alat bukti lain seperti keterangan saksi dan lain-lain. Dan masih perlu melalui kegiatan pendaftaran tanah supaya dapat menjadi sertipikat. Tetapi dalam hal mendesak seperti untuk kepentingan umum bukti-bukti lama tersebut dapat digunakan dalam rangka pembuktian untuk memperoleh ganti kerugian.

\section{Daftar Bacaan}

\section{Buku}

Urip Santoso, Hukum Agraria Kajian Komprehensif (Prenadamedia Group 2012).

Sri Hajati et al., Buku Ajar Politik Hukum pertanahan (Airlangga University Press 2018).

Sri Winarsi, Kedudukan Badan Pertanahan Nasional di Era Otonomi Daerah (Airlangga University Press 2018).

Waskito dan Hadi Arnowo, Penyelenggaraan Pendaftaran Tanah di Indonesia (Prenadamedia Group 2019).

Philipus M. Hadjon et al., Pengantar Hukum Administrasi Indonesia (Gadjah Mada University Press 2015).

\section{Jurnal}

Dadi Arja Kusuma dan Sahnan Rodliyah, 'Sertifikat Hak Milik Atas Tanah Sebagai Alat Bukti Hak Yang Kuat' (2017) 5 Jurnal IUS.

Yulyanti Rampengan, 'Kedudukan Hukum Registrasi Desa (LETTER C) Dalam Pembuktian Hak Milik Atas Tanah Menurut UUPA No.5 Tahun 1960’, (2016) 4 Lex Administratum. 
128 | Irsyadilla Hafizh: Keabsahan Bukti Lama...

\section{Laman}

Hukum Online, 'sengketa kepemilikan tanah' (Hukum Online 2005), <www. hukumonline.com>, accessed on 1 November 2019.

KBBI, 'itikad baik', (KBBI 2019), <www.kbbi.web.id> , accessed on 2 December 2019.

How to cite: Irsyadilla Hafizh Heru Sadjarwo, 'Keabsahan Bukti Lama Berupa Letter C Desa Dalam Kepemilikan Hak Atas Tanah' (2020) Vol. 3 No. 1 Notaire. 